変換し, 異分野の協調活動によりコンセブトの創造へ と向かうことが製品の市場競争力回復には重要である との認識が高まった。

こうした背景から 1994 年は PDM (Product Data Management）が注目を集めた。これは筡品設計生 産に関する技術，デー夕を一元管理するシステムであ り，CEの一つの基盤技術となる．設計生産デー夕の 一元管理は以前にも試みられていたが，雨者の相違 は, 従来の製品開発では固定組織を基本として, 設計 から生産への逐次処理を考えたのに対し，PDMで は, 顧客要求の著しい多様化, 複雑化に適切に対応す るために，業務の活動組織を再整理し，それらを機能 的に独立な単位に分割し，目的に合わせそれらを再編 成する。これにより既存技術，デー夕の有効活用と大 幅に変化する要求, 条件への即時対応を目指す。その 実現には, 各活動組織単位ごとに目的と処理方法を外 部に透明化する必要があり，情報共有を容易にするイ ンフラと情報システムが重要となる。

CSCW (Computer Supported Cooperalive Work) は, 分散化する計算機環境の有効利用を指向したシー ズ駆動の技術であるが, 産業界の大きな変化は協調活 動支援の情報システムへのニーズを㙞大させ, $\mathrm{CSCW}$ 技術も急速に発達してきた。とくに最近は Internet がインフラとして注目を浴びている.

また仮想現実（VR）は，そのインタラクティブ性 のゆえに Virtual Cooperation, Virtual Manufacturing 等の自律分散的な業務組織や製品開発方式実現に 有力な技術として新しい研究が開始されつつある.日 本では技術の伝承が言語よりも挙動（beiavior）を 中心として行われてきた歴史があり，VRはこうした 非言語的コミュニケーション支援技術としても最近注 目を集めている。

〔福田 収一 東京都立科学技術大学〕

\section{5・4・4 マイクロマシン技術関連行事として} は, 設計工学システム部門, ロボティクスメカトロニ クス部門が，オーガナイズドセッション，インターナ ショナルセッション等を行った。

ASME/WAM では, Dynamic Systems; Division で 15 論文が, Heat Transfer Division では Microscale Heat Transfer のシンポジウムで 9 論文が, Fluid Dynamics Division $の$ Application of Microfabrication to Fluid Mechanics のシンポジゥムでは 10 論文が発表された。

大磯で開催されたIEEE/MEMS '94では, 口頭発 表 35 件, 招待講演 3 件, ポス夕 25 件が発渍された。
通商産業省のプロジェクトが関心を引いていることも あり，多数の参加者を集めていた。日本からの研究発 表は，口頭で 16 件，ポス夕で 12 件であった。

一方ヨーロッパでは, MST'94 (Micro System Technology '94）が開催された。総発表件数は 162 件 (ドイツからの発表 105 件，いちばん多かった発表は, 加工技術と材料）であった. MST'94では展示も同 時に行われた。ヨーロッパでは旧東側が新規に参加し 始めているため, 研究者人口が急膨張している。 ま た，中小企業の本分野への参入を支援するプログラム があり，その成果が会議の論文集にも掲載されてい た. European Strategic Round Table Discussion が，NEXUSに関連してMST' 94 の会場で開催され たことも記しておこう。

SR 光を用いる LIGA 技術は, 依然ドイツが先頭を 切っており，アメリカが追従する形になっている. 我 が国からの発表は，国際的には依然として皆無であ る.アメリカでは, ARPAの援助により設立された ノースキャロライナの微細加工センタ (MCNC) が, シリコンと LIGA の試作サービスを継続している. ドイツのカールスルーエ研究セン夕（前原子核研究セ ンタ)も，同様の試作サービスを, LEMA（LIGA Experiment for Multiple Application）と称して開始 した。費用は DM $950 て ゙ \mathrm{MCNC}$ と違って, 誰でも申 込める.

IMM (Institute of Microtechnology Mainz) は, LIGA ニュース発刊のアナウンスを行った. LIGAに 関しては, 台湾, 韓国, 中国などでも基礎的な研究が 進められているが，特に台湾が熱心である．我が国で は, 先端加工機械技術振興協会が, LIGA 技術に関する 研究者および技術者の意識調查を始めた。国内では， LIGA に適した SR 光設備を整備する動きが, 数箇所 で活発になってきた、スイス,フランス,ドイツ等でLIGA 用の新しい専用リングの建設が計画されている.

欧米ではマイクロマシン分野で一般への技術情報サ 一ビスに，インターネットが積極的に利用されている ことは注目に值する。例えば, アメリカの MEMS. EDU, ヨーロッパの NEXUS の文書情報サーバ,スイ スで計画中の SR 設備の SLS サーバ及びそのほかの 国の SR 設備のサーバなどがすでに稼働している。な かには, シリコンマイクロマシニングの詳細な情報の ダウンロードが可能な場合もある.

アムステルダムでのIEEE/MEMS'95において, 欧米での実用性を重要視する傾向が一段と強く感じら れた。【梅田章工業技術院計哩研究所〕 